\title{
A bibliometric analysis of publications on trauma in critical care medicine during 1980-2018: A holistic view
}

\author{
다 Onur Karaca, M.D., ${ }^{1}$ 다 Cem Emir Güldoğan, M.D. ${ }^{2}$
}

${ }^{1}$ Depatment of Anesthesiology and Reanimation, Aksaray University Training and Research Hospital, Aksaray-Turkey

${ }^{2}$ Department of General Surgery, İstinye University Liv Hospital Ankara, Ankara-Turkey

\begin{abstract}
BACKGROUND: There is not a holistic bibliometric study evaluating the publications in the literature even though trauma is a paramount subject in the field of critical care. This study aimed to investigate the important articles and journals receiving the most citations and publishing the most articles, revealing international cooperation and uncovering trend topics in this subject as a consequence of analyzing articles on trauma in the field of critical care published between 1980 and 2018 using bibliometric analysis methods.

METHODS: Publication scan in this study was performed using Web of Science (WoS) database. Literature review was limited to only publications indexed in the field of Critical Care. "Trauma" was used as the keyword to reach relevant publications. Linear regression analysis was performed to predict the number of articles foreseen to be published in the upcoming years in the subject of trauma.

RESULTS: As a result of the literature review, a total of $1085 \mathrm{I}$ publications were found. Six thousand four hundred and eighty-nine (59.8\%) of these publications were under the category of article. First three countries with the most publications were respectively as the United States of America (4096) (63.I\%), Canada (40I) and Germany (380). Turkey ranked 21 with $4 \mathrm{I}$ publications. The article titled "Evaluating trauma care - the triss method" published in 1987 had received the most citations. The journal with the most publications and citations was "Journal of Trauma Injury Infection and Critical Care".
\end{abstract}

CONCLUSION: This study will be a useful guide to all scientists and clinicians conducting research on trauma in critical care.

Keywords: Bibliometric analysis; critical care; trauma; trends.

\section{INTRODUCTION}

Trauma can be defined as injury that arises from an acute exposure to mechanic, thermal, electric or chemical energy. [1,2] Trauma maintains a significant health issue rising mortality and morbidity rates with the contribution in technological advancements, accidents and acts of violence. Some studies have indicated that trauma-related deaths rank fifth in all-cause deaths for every age group in the United States of America. ${ }^{[3]}$ Critical care units, which are vital centers to prevent primary and secondary damage infliction at the time of trauma and as a direct result of trauma itself, are multidisciplinary structures dealing with potentially life-threatening diseases and conditions. These units are special with airway support, mechanical ventilation, current treatment methods, efficient application of drugs, and monitorization techniques. ${ }^{[4]}$

Bibliometry can be defined as a holistic analysis of written publications like books or articles using various statistical methods. ${ }^{[5,6]}$ Parallel to the gradual increase in the number of publications on worthy databases, such as Web of Science, Pubmed, and Scopus, the value of bibliometric analyses ensuring the evaluation of the publications holistically rises every passing day. ${ }^{[7,8]}$ The most impactful publications, institutions, active journals, international cooperation and trend topics in one subject are revealed, and these studies act as a guide to researchers. ${ }^{[9-10]}$ Thanks to bibliometric studies, researchers

Cite this article as: Karaca O, Güldoğan CE. A bibliometric analysis of publications on trauma in critical care medicine during 1980-2018:

A holistic view. Ulus Travma Acil Cerrahi Derg 2020;26:287-295.

Address for correspondence: Onur Karaca, M.D.

Aksaray Üniversitesi Eğitim ve Araştıma Hastanesi, Anesteziyoloji Anabilim Dalı, 68200 Aksaray, Turkey

Tel: +90382 - 2129109 E-mail: asalkaraca@gmail.com

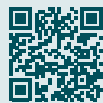

Ulus Travma Acil Cerrahi Derg 2020;26(2):287-295 DOI: 10.14744/tjtes.2020.6I595 Submitted: 07.02.2020 Accepted: 28.02.2020 Online: 04.03.2020

Copyright 2020 Turkish Association of Trauma and Emergency Surgery 
can access information on a subject in a short time through these studies summarizing the literature. ${ }^{[1]}$

There is not a holistic bibliometric study evaluating the publications in the literature although trauma is a paramount subject in the field of critical care. This study aimed to investigate the important articles and journals receiving the most citations and publishing the most articles, revealing international cooperation and uncovering trend topics in this subject in consequence of analyzing articles on trauma in the field of critical care published between 1980 and 2018 using bibliometric analysis methods.

\section{MATERIALS AND METHODS}

Publication scan in this study was addressed using the Web of Science (WoS) database. Literature review was limited to only publications indexed in the field of Critical Care. "Trauma" was used as the keyword to reach relevant publications (Title: (trauma) Refined by Web of Science Categories: (Critical Care Medicine) Timespan: 1975-2018. Indexes: SCl-Expanded, $\mathrm{SSCl}, \mathrm{A} \& \mathrm{HCl}, \mathrm{CPCl}-\mathrm{S}, \mathrm{CPCl}-\mathrm{SSH}, \mathrm{BKCl}-\mathrm{S}, \mathrm{BKCl}-\mathrm{SSH}, \mathrm{ESCl}$ ).

Bibliometric analyses and network visualization were performed using VOSviewer (Version I.6.10) package program. [12] "Gunn Map" (http://lert.co.nz/map/) online world map was used to show the publication distribution of world countries. SPSS (Version 22.0, SPSS Inc., Chicago, IL, ABD, License: Hitit University) program was used for statistical analyses. Data distribution was evaluated using the Shapiro-Wilk test. Linear regression analysis was performed to predict the number of articles foreseen to be published in the upcoming years in the subject of trauma. $P<0.05$ was accepted as statistically significant.

\section{RESULTS}

As a result of the literature review, a total of $1085 \mathrm{I}$ publications were found. Six thousand four hundred and eighty-nine
$(59.8 \%)$ of these publications were indexed under the category of article, 2194 (20.2\%) under meeting abstracts, 1502 (I3.8\%) under proceedings papers, I I 24 (I0.3\%) under editorial materials, 460 (4.2\%) under reviews, and 634 (6\%) under other categories (such as letter, book chapter, book review, note, correction, discussion, biographical item). Only 6489 papers published under the category of the article were downloaded through WoS and analyzed using bibliometric methods.

Ninety-eight point seventy-five percent $(n=6408)$ of the articles were published in English and the rest of the articles was published in other languages (German: $n=55$, Spanish: $n=25$, Turkish: $n=1$ ). Six thousand four hundred and eighty-nine publications received 195429 citations in total. Mean citation count per article was 30 . The h-index value of all articles was 144.

\section{Active Institutions}

The highest number of publications was produced in the following institutions: Washington University $(n=238)$, Maryland University $(n=195)$, Pittsburgh University $(n=165)$, Toronto University $(n=154)$, California San Francisco University $(n=140)$, and Colorado University $(n=140)$. Our most active institutions in Turkey were Ankara Numune Training and Research Hospital $(n=5)$ and Selcuk University $(n=5)$, respectively.

\section{Active Authors}

The first five authors contributing vastly to the literature concerning publication number were found respectively as follows: Moore EE. $(n=124)$, Inaba K. $(n=97)$, Demetriades D. $(n=93)$, Scalea TM. $(n=84)$, and Jurkovich $G .(n=8 I)$. The most active writers in Turkey Ustun M. E. $(n=5)$, followed by Duman A. $(n=4)$ and Gurbilek $M(n=4)$, respectively.

\section{Distribution of the Publications According to Years}

Figure I shows the distribution of the articles published on trauma according to years. 5-year (2019-2023) publication prediction numbers obtained by linear regression analysis are

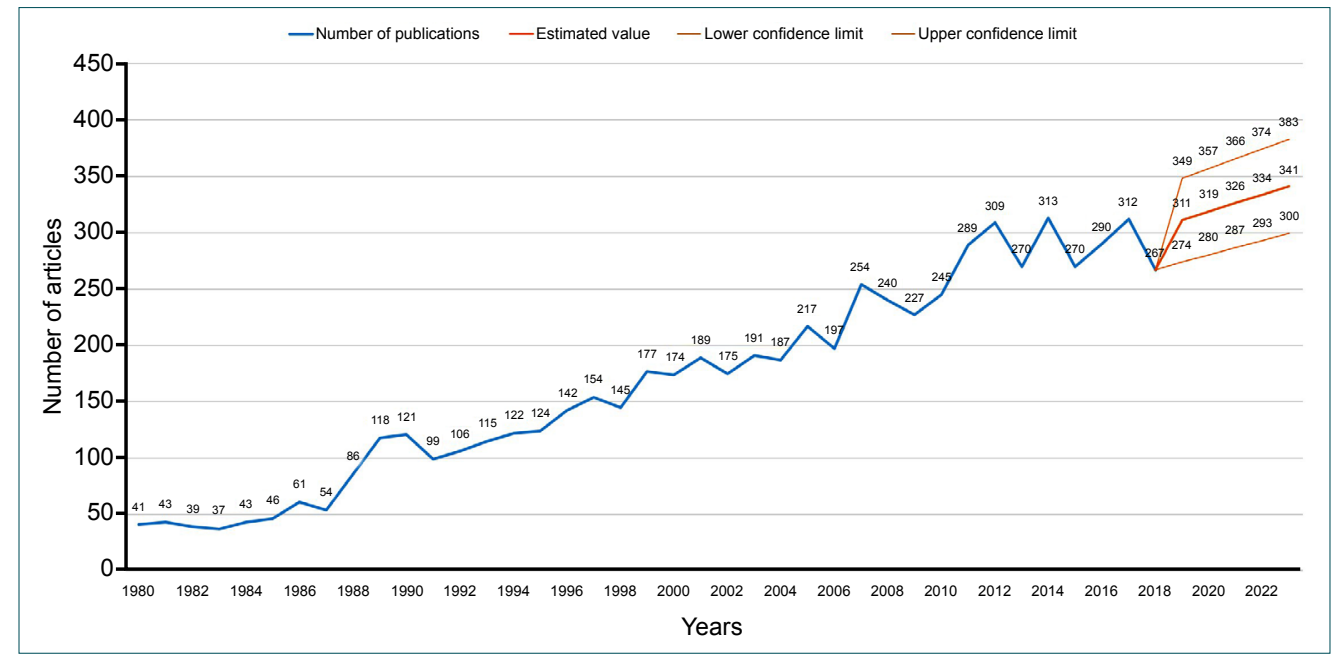

Figure 4. Distribution of the articles on trauma in critical care according to years. 
also given in Figure I. It was predicted that there would be $31 \mathrm{I}$ articles published in 2019 (95\% Cl: 274-349) and $34 \mathrm{I}$ articles (95\% Cl: 300-383) published in 2022.

\section{Articles Receiving Most Citations}

The first 15 articles on trauma receiving the most citations are given in Table I. In Turkey, the most cited study with a total of 6 I citations was "Prospective study investigating routine usage of ultrasonography as the initial diagnostic modality for the evaluation of children sustaining blunt abdominal trauma" that was published by Akgür et al.

\section{Active Countries}

The country with the highest number of publications was

Table I. The 15 most cited manuscripts on trauma in critical care medicine

\begin{tabular}{|c|c|c|c|c|c|c|}
\hline No & Article & Author & Journal & PY & TC & AC \\
\hline I & Evaluating trauma care - the triss method & Boyd, CR. et al. & $\begin{array}{l}\text { Journal of Trauma-Injury } \\
\text { Infection and Critical Care }\end{array}$ & 1987 & 1338 & 40,55 \\
\hline 2 & Epidemiology of trauma deaths - a reassessment & Sauaia, A. et al. & $\begin{array}{l}\text { Journal of Trauma-Injury } \\
\text { Infection and Critical Care }\end{array}$ & 1995 & 1193 & 47,72 \\
\hline 3 & A revision of the trauma score & Champion, HR. et al. & $\begin{array}{l}\text { Journal of Trauma-Injury } \\
\text { Infection and Critical Care }\end{array}$ & 1989 & 1134 & 36,58 \\
\hline 4 & $\begin{array}{l}\text { The major trauma outcome study - establishing } \\
\text { national norms for trauma care }\end{array}$ & Champion, HR. et al. & $\begin{array}{l}\text { Journal of Trauma-Injury } \\
\text { Infection and Critical Care }\end{array}$ & 1990 & 793 & 26,43 \\
\hline 5 & Early coagulopathy predicts mortality in trauma & MacLeod, JBA. et al. & $\begin{array}{l}\text { Journal of Trauma-Injury } \\
\text { Infection and Critical Care }\end{array}$ & 2003 & 691 & 40,65 \\
\hline 6 & Trauma score & Champion, HR. et al. & Critical Care Medicine & 1981 & 636 & 16,31 \\
\hline 7 & $\begin{array}{l}\text { Impact of hemorrhage on trauma outcome: } \\
\text { an overview of epidemiology, clinical } \\
\text { presentations, and therapeutic considerations }\end{array}$ & Kauvar, DS. et al. & $\begin{array}{l}\text { Journal of Trauma-Injury } \\
\text { Infection and Critical Care }\end{array}$ & 2006 & 618 & 44,14 \\
\hline 8 & $\begin{array}{l}\text { Ten versus tpn following major abdominal- } \\
\text { trauma - reduced septic morbidity }\end{array}$ & Moore, FA. et al. & $\begin{array}{l}\text { Journal of Trauma-Injury } \\
\text { Infection and Critical Care }\end{array}$ & 1989 & 570 & 18,39 \\
\hline 9 & $\begin{array}{l}\text { Recombinant factor via as adjunctive therapy } \\
\text { for bleeding control in severely injured trauma } \\
\text { patients: two parallel randomized, placebo- } \\
\text { controlled, double-blind clinical trials }\end{array}$ & Boffard, KD. et al. & $\begin{array}{l}\text { Journal of Trauma-Injury } \\
\text { Infection and Critical Care }\end{array}$ & 2005 & 526 & 35,07 \\
\hline 10 & $\begin{array}{l}\text { Management of bleeding and coagulopathy } \\
\text { following major trauma: an updated } \\
\text { European guideline }\end{array}$ & Spahn, DR. et al. & Critical Care & 2013 & 510 & 72,86 \\
\hline II & $\begin{array}{l}\text { The effect of selective decontamination of the } \\
\text { digestive-tract on colonization and } \\
\text { infection-rate in multiple trauma patients }\end{array}$ & Stoutenbeek, CP. et al. & Intensive Care Medicine & 1984 & 474 & 13,17 \\
\hline 12 & $\begin{array}{l}\text { Prospective study of blunt aortic injury: } \\
\text { multicenter trial of the American } \\
\text { association for the surgery of trauma }\end{array}$ & Fabian, TC et al. & $\begin{array}{l}\text { Journal of Trauma-Injury } \\
\text { Infection and Critical Care }\end{array}$ & 1997 & 471 & 20,48 \\
\hline 13 & $\begin{array}{l}\text { Acute coagulopathy of trauma: hypoperfusion } \\
\text { induces systemic anticoagulation and } \\
\text { hyperfibrinolysis }\end{array}$ & Brohi, K. et al. & $\begin{array}{l}\text { Journal of Trauma-Injury } \\
\text { Infection and Critical Care }\end{array}$ & 2008 & 460 & 38,33 \\
\hline 14 & $\begin{array}{l}\text { Management of bleeding following major trauma: } \\
\text { an updated European guideline }\end{array}$ & Rossaint, R. et al. & Critical Care & 2010 & 458 & 45,8 \\
\hline 15 & $\begin{array}{l}\text { Blood transfusion, independent of shock severity, } \\
\text { is associated with worse outcome in trauma }\end{array}$ & Malone, DL. et al. & $\begin{array}{l}\text { Journal of Trauma-Injury } \\
\text { Infection and Critical Care }\end{array}$ & 2003 & 437 & 25,71 \\
\hline
\end{tabular}

PY: Publication Year; TC: Total Citation; AC: Average Citations per Year. 
the United States of America with 4096 publications (63.1\%). The United States of America was followed respectively by Canada (40I), Germany (380), England (377), Australia (239), the Netherlands (163), France (I37), Japan (I I I), China (103), Italy (96), Austria (82), South Africa (76), Switzerland (76), Israel (75), Sweden (72), Spain (69), Taiwan (56), Norway
(48), Scotland (48), Denmark (44), and Turkey (4I). The distribution of the publications according to world countries is shown in Figure 2. Six thousand four hundred and eighty-nine articles were written by authors from III world countries. Figure 3 shows the network map of international cooperation among 53 world authors who have at least five publications.

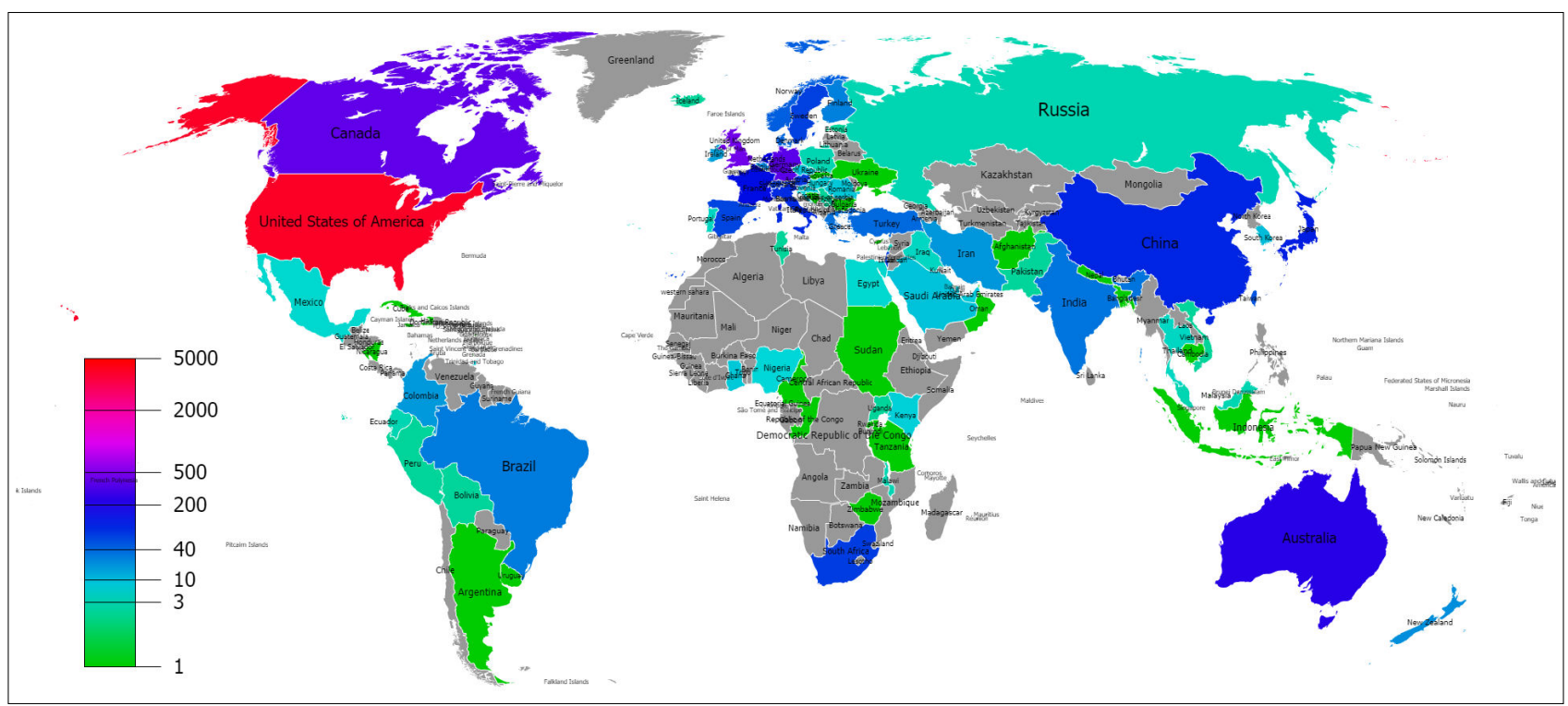

Figure 2. Distribution of the articles on trauma in critical care according to world countries. Footnote: In the indicator given at the bottom left of the figure, productivity increases from green to red.

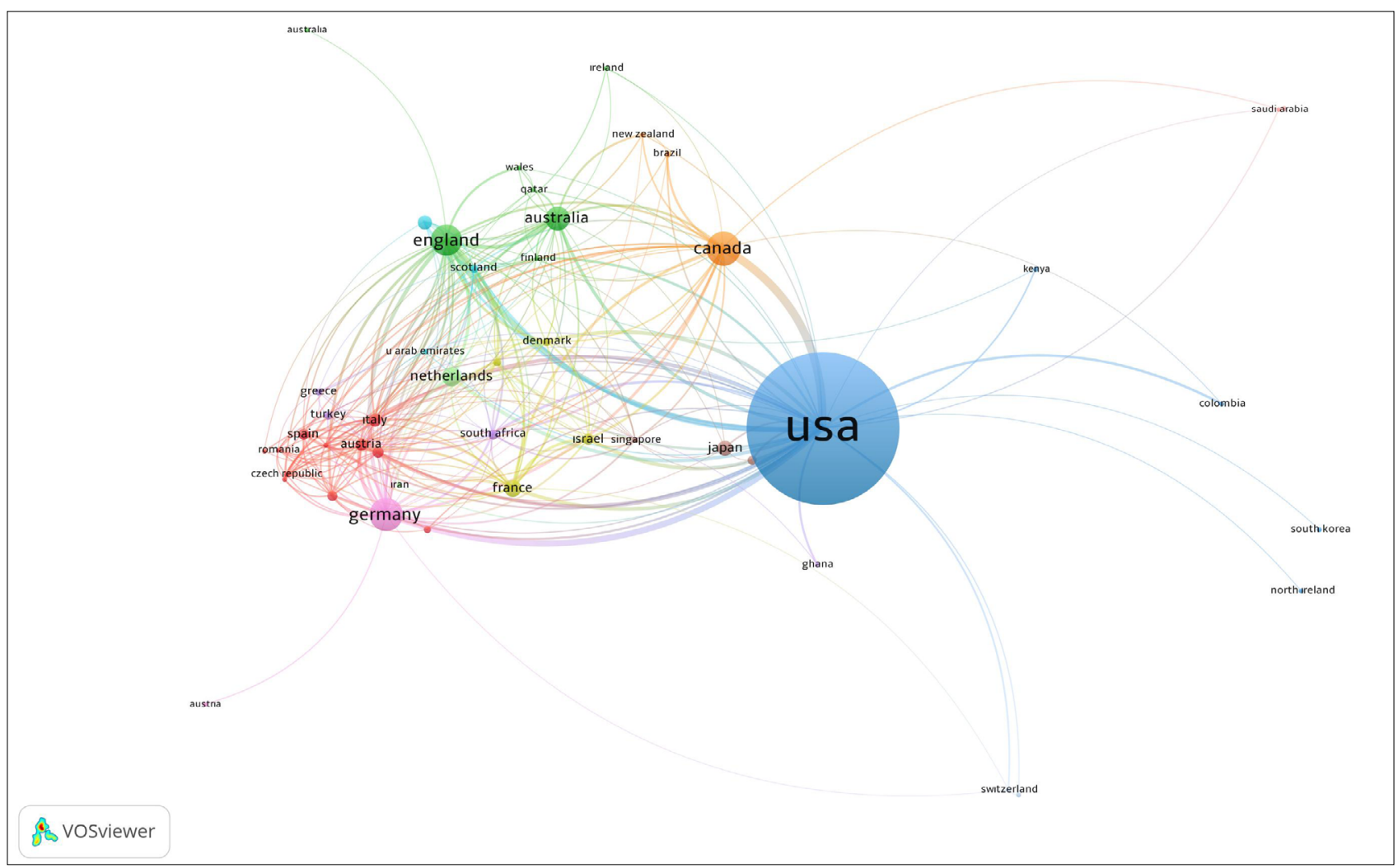

Figure 3. Network visualization map for international cooperation of world countries publishing articles on trauma in critical care. Footnote: The size of the circle shows a large number of articles. The colors indicate the clusters and the thickness of the lines indicates the strength of the relationship. 


\section{Active Journals}

There were a total of 60 journals publishing the highest number of articles on trauma. Table 2 gives the first 35 journals among the 60 publishing at least five articles. Figure 4 demonstrates the citation network map among these journals.

\section{Trend Topics}

Eight thousand thirty-five keywords were used in 6489 articles. One hundred and seven keywords used at least 20 times are shown in Table 3. The network map obtained as a result of the clustering analysis for these keywords is presented in Figure 5 (Footnote: Indicator shows current publications from blue to red). Figure 6 demonstrates the network map of the trend topics according to the years of the keywords used. Moreover, the network map obtained according to the citation count of the articles with these keywords is given in Figure 7.

\section{DISCUSSION}

We presented summarized information of 6489 articles published in a long time (1975-2018) on the subject of trauma in critical care in this comprehensive bibliometric study. The most active institution was determined as the Washington University, and the most actively producing author was found as Moore EE. When the publications were investigated according to years, publication trends that started to increase in 1988 demonstrated a linear increase and have reached approximately 300 articles in recent years. According to the result of the regression analysis, it is seen that research conducted on this subject will increase every passing day.

The articles receiving the most citations on this subject were that of Boyd et al. titled "Evaluating trauma care - the triss method" published in 1987 in the Journal of Trauma-Injury Infection and Critical Care and that of Sauaia et al. titled "Epidemiology of trauma deaths - a reassessment" published in 1995. Furthermore, salient studies as regards mean citation count were that of Spahn et al. (2013) titled "Management of bleeding and coagulopathy following major trauma: an updated European guideline" and that of Rossaint et al. (2010) titled "Management of bleeding following major trauma: an updated European guideline". We are of the opinion that these are studies that should be primarily read by researchers interested in this subject.

Table 2. Active journals on trauma in critical care medicine

\begin{tabular}{|c|c|c|c|c|c|c|c|}
\hline Journals & $\mathbf{R C}$ & $\%$ & C & Journals & $\mathbf{R C}$ & $\%$ & C \\
\hline $\begin{array}{l}\text { Journal of Trauma Injury Infection } \\
\text { and Critical Care }\end{array}$ & 3109 & 47.9 & 131167 & Anaesthesia and Intensive Care & 18 & 0.2 & 266 \\
\hline $\begin{array}{l}\text { Injury International Journal of } \\
\text { The Care of the Injured }\end{array}$ & 962 & 14.8 & 14253 & Pediatric Critical Care Medicine & 17 & 0.2 & 354 \\
\hline $\begin{array}{l}\text { Journal of Trauma and Acute } \\
\text { Care Surgery }\end{array}$ & 908 & 13.9 & $1279 \mid$ & Essentials of Trauma Anesthesia & 15 & 0.2 & 9 \\
\hline Shock & 225 & 3.4 & 6660 & Indian Journal of Critical Care Medicine & 14 & 0.2 & 18 \\
\hline Critical Care Medicine & 211 & 3.2 & 9748 & Neurocritical Care & 13 & 0.2 & 120 \\
\hline Journal of Neurotrauma & 147 & 2.2 & 4595 & Anasthesiologie Intensivmedizin & 12 & 0.1 & 8 \\
\hline Journal of Trauma Nursing & 137 & 2.1 & 364 & Minerva Anestesiologica & 12 & 0.18 & 100 \\
\hline Intensive Care Medicine & 90 & 1.3 & 3651 & Critical Care Nurse & 11 & 0.17 & 50 \\
\hline Critical Care & 86 & 1.3 & 4971 & $\begin{array}{l}\text { American Journal of Respiratory } \\
\text { And Critical Care Medicine }\end{array}$ & 9 & 0.13 & 729 \\
\hline Resuscitation & 75 & I.I & 2004 & Journal of Acute Disease & 9 & 0.13 & 3 \\
\hline Critical Care Clinics & 55 & 0.8 & 553 & $\begin{array}{l}\text { Trauma Critical Care and Surgical Emergencies } \\
\text { A Case and Evidence-Based Textbook }\end{array}$ & 9 & 0.13 & 3 \\
\hline Journal of Critical Care & 48 & 0.7 & 537 & European Manual of Medicine & 8 & 0.12 & 10 \\
\hline Burns & 45 & 0.6 & 507 & $\begin{array}{l}\text { General Trauma Care And Related Aspects } \\
\text { Trauma Surgery II }\end{array}$ & 8 & 0.12 & 10 \\
\hline $\begin{array}{l}\text { Anasthesiologie Intensivmedizin } \\
\text { Notfallmedizin Schmerztherapie }\end{array}$ & 40 & 0.6 & 143 & American Journal of Critical Care & 7 & 0.10 & 72 \\
\hline Current Trauma Reports & 40 & 0.6 & 37 & Annals of Intensive Care & 7 & 0.10 & 54 \\
\hline Chest & 32 & 0.4 & 1204 & Anaesthesia Critical Care Pain Medicine & 6 & 0.09 & 20 \\
\hline Medicina Intensiva & 27 & 0.4 & 164 & Journal of Intensive Care Medicine & 5 & 0.07 & 14 \\
\hline Journal of Burn Care Research & 20 & 0.3 & 167 & & & & \\
\hline
\end{tabular}

RC: Record Count; C: Number of Citation. 


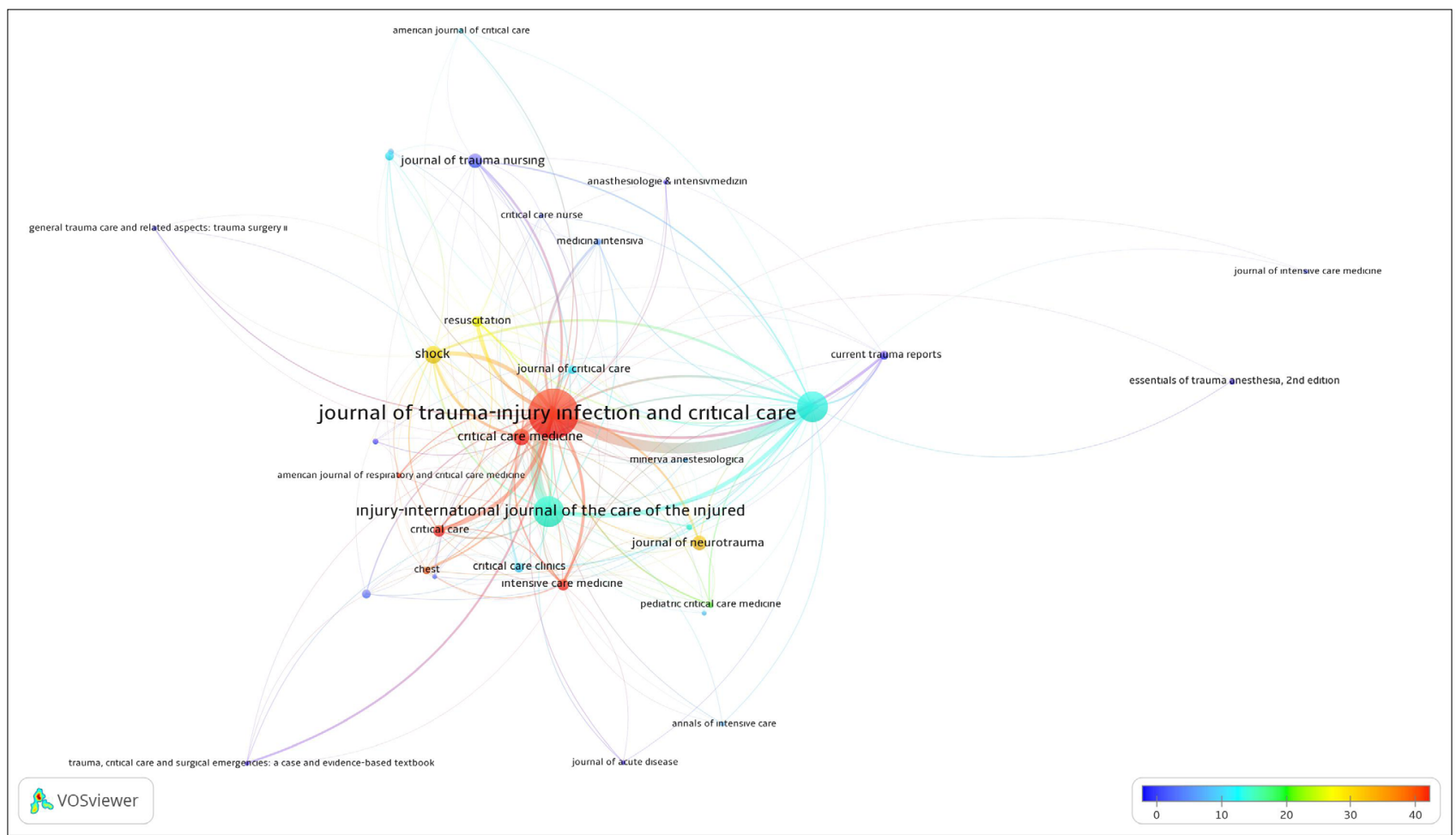

Figure 4. Network visualization map for citation analysis of active journals publishing articles on trauma in critical care. Footnote: The size of the circle shows a large number of articles. The colors indicate the clusters and the thickness of the lines indicates the strength of the relationship.

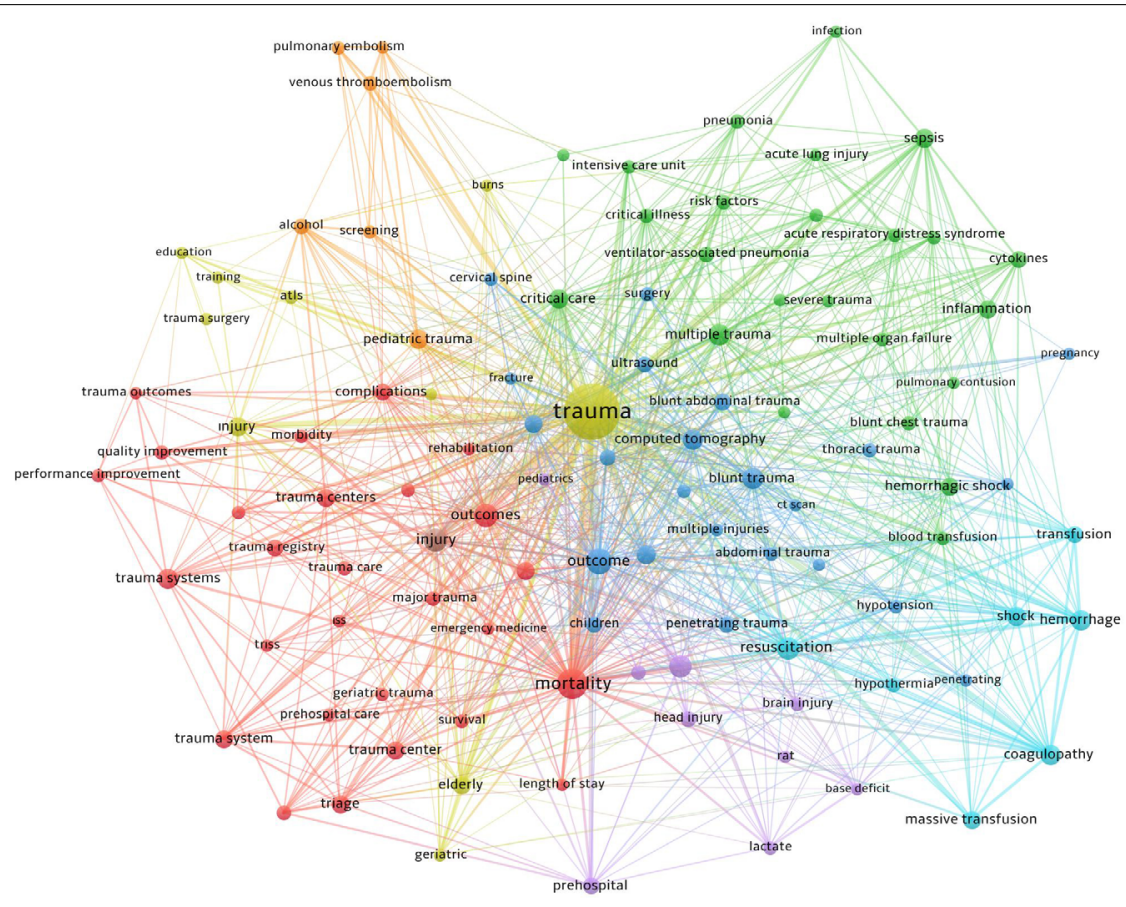

Figure 5. Clustering network visualization map for keyword analysis used in articles on trauma in critical care. Footnote: Indicator shows current publications from blue to red.

When the countries producing publications were assessed, economically developed countries were found to be more efficient. A significant correlation between academic productivity and economic development has been shown in many studies in the literature..$^{7,8,10]}$ Dokur et al. ${ }^{[13]}(2018)$ have indicated in a bibliometric study determining the 100 most cited articles in traumatology that 70 of the first 100 cited articles were supported by institutions providing funds. We are of the opinion 
Table 3. The first 107 trend keywords on trauma in critical care medicine

\begin{tabular}{|c|c|c|c|c|c|c|c|}
\hline Keyword & 0 & Keyword & 0 & Keyword & 0 & Keyword & 0 \\
\hline trauma & 1367 & trauma centers & 56 & hypothermia & 30 & damage control & 23 \\
\hline mortality & 259 & trauma system & 56 & blood transfusion & 29 & geriatric & 23 \\
\hline outcome & 153 & transfusion & 53 & brain injury & 29 & length of stay & 23 \\
\hline injury & 121 & complications & 52 & cervical spine & 29 & prehospital care & 23 \\
\hline outcomes & 121 & prehospital & 52 & mechanical ventilation & 29 & rat & 23 \\
\hline resuscitation & 115 & blunt abdominal trauma & 51 & multiple organ failure & 29 & rehabilitation & 23 \\
\hline traumatic brain injury & 112 & cytokines & 49 & pulmonary embolism & 29 & severe trauma & 23 \\
\hline blunt trauma & 97 & trauma registry & 47 & screening & 29 & trauma patients & 23 \\
\hline multiple trauma & 95 & head injury & 46 & $\begin{array}{l}\text { acute respiratory } \\
\text { distress syndrome }\end{array}$ & 28 & burns & 22 \\
\hline trauma systems & 87 & penetrating trauma & 45 & survival & 28 & emergency medicine & 22 \\
\hline computed tomography & 85 & alcohol & 43 & injury severity score & 28 & laparotomy & 22 \\
\hline coagulopathy & 79 & children & 41 & intensive care unit & 27 & pulmonary contusion & 22 \\
\hline hemorrhage & 78 & polytrauma & 41 & lactate & 27 & ct scan & 21 \\
\hline shock & 76 & ultrasound & 40 & abdominal trauma & 26 & deep venous thrombosis & 21 \\
\hline critical care & 72 & $\begin{array}{l}\text { ventilator-associated } \\
\text { pneumonia }\end{array}$ & 39 & quality of life & 26 & education & 21 \\
\hline Injury & 72 & emergency medical services & 37 & ards & 25 & fracture & 21 \\
\hline sepsis & 68 & quality improvement & 37 & atls & 25 & pediatrics & 21 \\
\hline pediatric & 66 & major trauma & 36 & geriatric trauma & 25 & penetrating & 21 \\
\hline pediatric trauma & 66 & trauma care & 36 & hypotension & 25 & prognosis & 21 \\
\hline triage & 65 & venous thromboembolism & 36 & morbidity & 25 & trauma surgery & 21 \\
\hline wounds and injuries & 65 & head trauma & 35 & pelvic fracture & 25 & ISS & 21 \\
\hline trauma center & 60 & blunt chest trauma & 34 & performance improvement & 25 & base deficit & 20 \\
\hline elderly & 57 & risk factors & 34 & acute lung injury & 24 & infection & 20 \\
\hline epidemiology & 57 & surgery & 33 & injury severity score & 24 & intensive care & 20 \\
\hline hemorrhagic shock & 57 & critical illness & 32 & multiple injuries & 24 & pregnancy & 20 \\
\hline inflammation & 57 & pneumonia & 32 & trauma outcomes & 24 & training & 20 \\
\hline massive transfusion & 56 & thoracic trauma & 32 & triss & 24 & & \\
\hline
\end{tabular}

O: Number of occurrences.

that the contribution of South Africa and Turkey, two developing countries, is related to the high rate of trauma prevalence in these countries. Especially from developing countries, it has been determined that Turkey was not involved in the first twenty countries. Considering international cooperation, regional cooperation was found to be made geographically.

Active journals producing the most publications were determined as the Journal of Trauma Injury Infection and Critical Care, Injury International Journal of The Care of the Injured and the Journal of Trauma and Acute Care Surgery. However, impactful journals receiving citations were as follows: Trauma Injury Infection and Critical Care, Critical Care Medicine, Critical Care, Intensive Care Medicine, Chest, and American Journal of Respiratory and Critical Care Medicine. Researchers wishing to publish studies in this subject are advised to consider these journals.
The results of keyword analysis revealed that although subjects, such as brain injury, head injury, and chest injury, were studied in first years, subjects, such as cytokines, acute respiratory distress syndrome, pneumonia, pulmonary embolism, inflammation, and hemorrhagic shock, were researched in subsequent years, and trend topics in recent years were determined to be outcomes, geriatric trauma, quality improvement, education, venous thromboembolism, transfusion, and coagulopathy. Outcomes and transfusion subjects preserved their significance in all years. Topics with the highest citation rates were detected as transfusion, coagulopathy, hemorrhage and ultrasound.

Our study is the first comprehensive bibliometric study conducted on this subject. Literature review put forth that Zhang et al. ${ }^{[14]}(2018)$ have determined at least 2000 cited articles on critical care as a result of the bibliometric analyses they con- 
ducted. Li et al. ${ }^{[15]}$ (20I8) have determined the most cited I00 articles on Severe Traumatic Brain Injury in their bibliometric study. In this study, all articles published between 1980 and 2018 on the subject of trauma in the field of critical care were analyzed and the publications were evaluated holistically with analyses, such as international cooperation, journal analyses, and trend topic analyses in addition to citation analyses.

A limitation to our study was that only the WoS database was used for article retrieval. Other databases, like PubMed

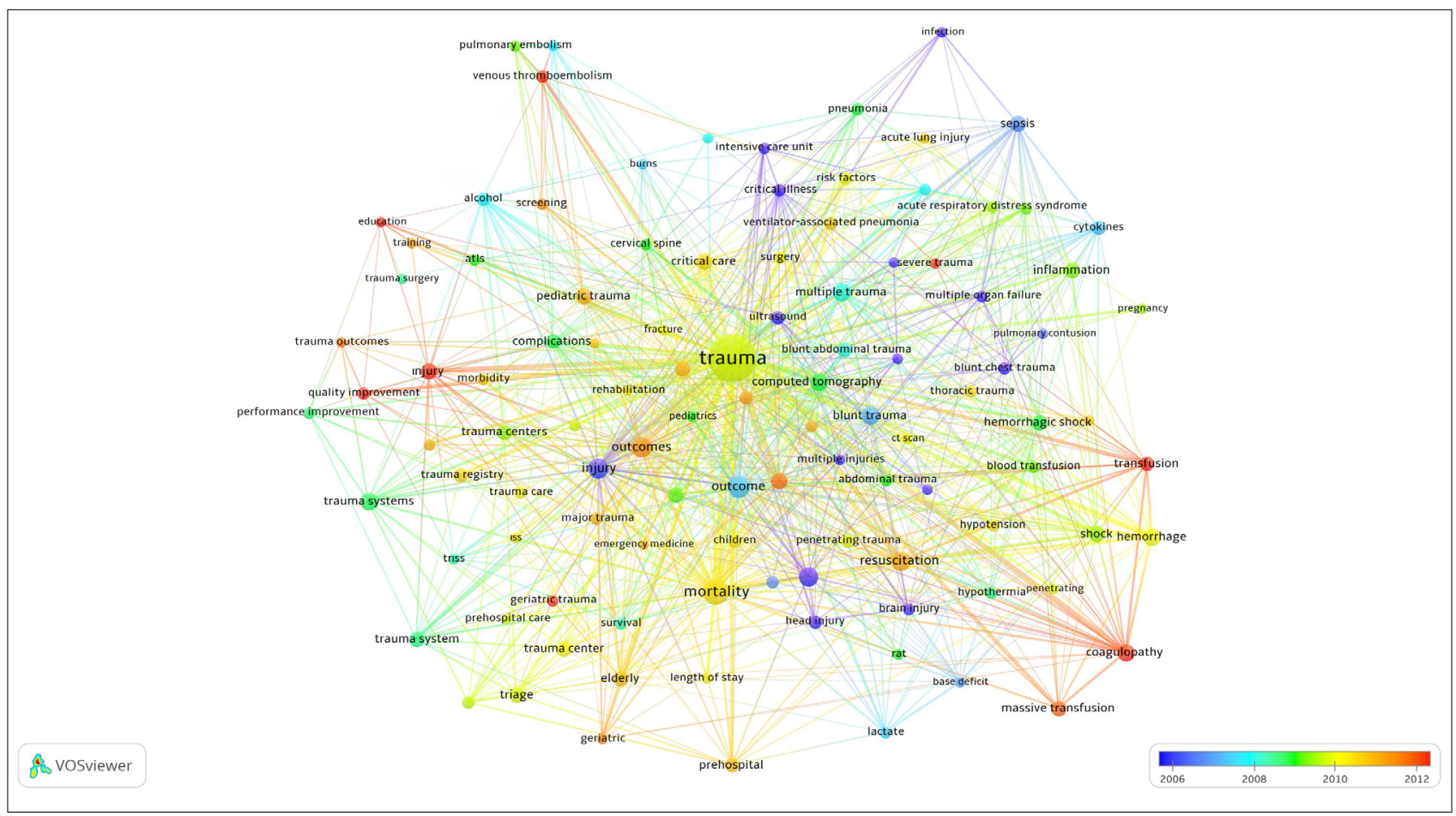

Figure 6. Network visualization map for trend words of the keywords used in articles on trauma in critical care. Footnote: Indicator shows current publications from blue to red.

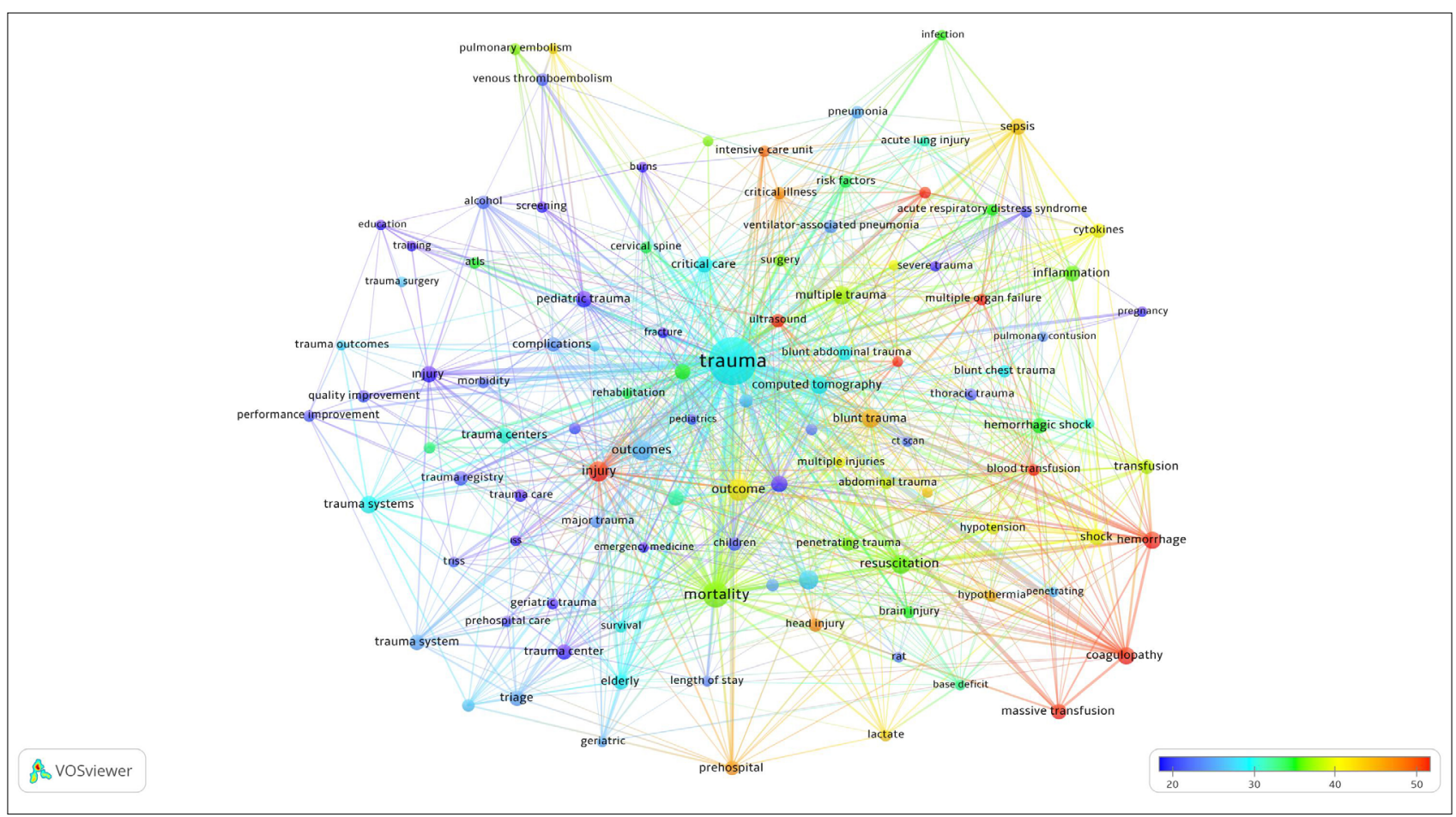

Figure 7. Network visualization map for most cited words of the keywords used articles on trauma in critical care. Footnote: The number of citations from blue to red (blue-green-yellow-red) increases. 
and Scopus, were not considered. In analyses conducted with more than one database, there is an issue of including the same articles more than once to the analyses. Moreover, it can be said that WoS is a relatively important database since it indexes articles published in journals with high impact scores.

\section{Conclusion}

Summarized information was provided to researchers on trauma in critical care in this study. Bibliometric analyses demonstrated the most important articles cited and the journals receiving citation on the subject "trauma in critical care" and those producing the highest number of publications and indicated international cooperation and trend topics on this subject.

\section{Peer-review: Internally peer-reviewed.}

Authorship Contributions: Concept: O.K., C.E.G.; Design: O.K., C.E.G.; Supervision: O.K., C.E.G.; Fundings: O.K., C.E.G.; Materials: O.K., C.E.G.; Data: O.K., C.E.G.; Analysis: O.K., C.E.G.; Literature search: O.K., C.E.G.; Writing: O.K., C.E.G.; Critical revision: O.K., C.E.G.

Conflict of Interest: None declared.

Financial Disclosure: The authors declared that this study has received no financial support.

\section{REFERENCES}

1. Boyd CR, Tolson MA, Copes WS. Evaluating trauma care: the TRISS method. Trauma Score and the Injury Severity Score. J Trauma 1987;27:370-37. [CrossRef]

2. Sauaia A, Moore FA, Moore EE, Moser KS, Brennan R, Read RA, et al. Epidemiology of trauma deaths: a reassessment. J Trauma 1995;38:185-93. [CrossRef]

3. Adıyaman E, Tokur ME, Mermi Bal Z, Gökmen AN, Koca U. Retro- spective analysis of trauma patients who were treated and followed in anesthesia intensive care unit. Turk J Intensive Care 2019;17:146-53.

4. George WW. Common Clinical Concerns in Critical Care Medicine. In: Butterworth IV JF, Mackey DC, Wasnick JD, editors. Morgan and Mikhail's Clinical Anesthesiology. 6th ed. New York: McGraw-Hill; 2018 p. 2097-145.

5. Ozsoy Z, Demir E. Correction to: Which Bariatric Procedure Is the Most Popular in the World? A Bibliometric Comparison. Obes Surg 2018;28:2353. [CrossRef]

6. Demir E. The Evolution of Spirituality, Religion and Health Publications: Yesterday, Today and Tomorrow. J Relig Health 2019;58:1-13.

7. Doğan G, Kayır S. Global Scientific Outputs of Brain Death Publications and Evaluation According to the Religions of Countries. J Relig Health 2020;59:96-112. [CrossRef]

8. Demir E, Comba A. The evolution of celiac disease publications: a holistic approach with bibliometric analysis. Ir J Med Sci 2020;189:267-76.

9. Doğan G, İpek H. The Development of Necrotizing Enterocolitis Publications: A Holistic Evolution of Global Literature with Bibliometric Analysis. Eur J Pediatr Surg 2019 Nov 27. doi:10.1055/s-0039-3400514. [Epub ahead of print]. [CrossRef]

10. Demir E, Yaşar E, Özkoçak V, Yıldırım E. The evolution of the field of legal medicine: A holistic investigation of global outputs with bibliometric analysis. J Forensic Leg Med 2020;69:101885. [CrossRef]

11. Yildırım E, Demir E. Comparative bibliometric analysis of fertility preservation. Ann Med Res 2019;26:1622-8. [CrossRef]

12. Van Eck NJ, Waltman L. Software survey: VOS viewer, a computer program for bibliometric mapping. Scientometrics 2010;84:523-38. [CrossRef]

13. Dokur M, Uysal E. Top 100 cited articles in traumatology: A bibliometric analysis. Ulus Travma Acil Cerrahi Derg 2018;24:294-302. [CrossRef]

14. Zhang Z, Van Poucke S, Goyal H, Rowley DD, Zhong M, Liu N. The top 2,000 cited articles in critical care medicine: a bibliometric analysis. J Thorac Dis 2018;10:2437-47. [CrossRef]

15. Li L, Ma X, Pandey S, Deng X, Chen S, Cui D, et al. The Most-Cited Works in Severe Traumatic Brain Injury: A Bibliometric Analysis of the 100 Most-Cited Articles. World Neurosurg 2018;113:e82-7. [CrossRef]

\section{ORIJINAL ÇALIŞMA - ÖZET}

\section{Yoğun bakım alanında travma konusunda 1980-2018 yılları arasında yapılan yayınların bibliyometrik analizi: Bütünsel yaklaşım}

\section{Dr. Onur Karaca, ${ }^{1}$ Dr. Cem Emir Güldoğan ${ }^{2}$}

${ }^{1}$ Aksaray Üniversitesi Tıp Fakültesi, Anesteziyoloji ve Reanimasyon Anabilim Dalı, Aksaray

${ }^{2}$ Istinye Üniversitesi Tıp Fakültesi Liv Hospital Ankara, Genel Cerrahi Anabilim Dalı, Ankara

AMAÇ: Yoğun bakım alanında travma konusunun önemli bir yeri olmasına rağmen halen bu konuda literatürdeki yayınların bütünsel olarak değerlendirildiği bir bibliyometrik araştırma bulunmamaktadır. Bu çalışmada 1980 ve 2018 yılları arasında yoğun bakım araştırma alanında yayınlanmış travma konusundaki makalelerin bibliyometrik analiz yöntemleri kullanılarak analiz edilmesi sonucunda; en fazla alıntı yapılan önemli makalelerin ve bu konudaki en fazla atıf alan ve yayın üreten dergilerin belirlenmesi, ülkelerarası işbirliklerinin ortaya konulması ve bu konudaki trend konuların ortaya çıkarılması amaçlanmıştır.

GEREÇ VE YÖNTEM: Araştırmamızda yayın taraması Web of Science (WoS) veri tabanı kullanılarak gerçekleştirildi. Literatür taraması sadece Yoğun Bakım araştırma alanında indekslenen yayınlarda yapıldı. İlgili yayınlara ulaşmak için arama anahtar kelimesi olarak "trauma” kullanıldı. Travma konusunda gelecek yıllarda yayınlanması öngörülen makale sayısını tahmin etmek amacıyla doğrusal regresyon analizi gerçekleştirildi. BULGULAR: Literatür taraması sonucunda toplam 10.85I yayın bulundu. Bu yayınların 6.489'u (59.8\%) makale kategorisinde idi. En fazla yayın yapan ilk üç ülke Amerika Birleşik Devletleri 4.096 (\%63. I) Kanada (40I) ve Almanya (380) idi. Türkiye 4 I yayınla 2I. sırada idi. En fazla atıfı I987 yılında yayınlanan "Evaluating trauma care - the triss method" başıılı makale almıştı. En fazla yayın üreten ve en çok atıf alan dergi "Journal of Trauma Injury Infection and Critical Care" idi.

TARTIŞMA: Bu çalışma yoğun bakımda travma konusunda araştırma yapan klinisyenler ve bilim adamları için faydalı bir rehber olacaktır. Anahtar sözcükler: Bibliyometrik analiz; travma; trendler; yoğun bakım.

Ulus Travma Acil Cerrahi Derg 2020;26(2):287-295 doi: 10.14744/tjtes.2020.61595 